\title{
The Effect of Political Institutions on the Use of Citizen Participation Programs
}

\author{
Youngmin $\mathrm{Oh}^{*}$ and Jongsun Park**
}

\begin{abstract}
Local governments' use of citizen participation programs is influenced by external environments, especially in the form of political institutions. Local governments decide to expand or limit citizen participation in administrative decision-making processes in response to political uncertainties created by different types of political institutions. Despite the importance of institutional contexts, few studies have examined the effects of these political institutions on the use of citizen participation programs. This study empirically tested whether political institutions affect the adoption of citizen participation programs. The results suggest that the council-manager form of government increases both the adoption of citizen participation mechanisms and the use of citizen participation programs in functional areas, while nonpartisan elections are associated only with the adoption of citizen participation mechanisms. At-large elections show no statistical association with either type of citizen participation. These findings suggest that local political contexts play important roles in the adoption of bureaucratic practices such as citizen participation programs and still support the classical assertion that public administration is closely connected to politics.
\end{abstract}

Keywords: institutions, citizen participation, political environments, councilmanager form of government, nonpartisan election, at-large election

* Youngmin Oh is an associate fellow in the Korea Institute of Public Finance. He received a $\mathrm{PhD}$ from the Askew School of Public Administration and Policy at Florida State University. His research interests are public performance management and measurement, public management, local governance, and institutions. E-mail: dowhat@kipf.re.kr

** Jongsun Park (corresponding author) is an assistant professor at Keimyung University. He received a PhD degree from the Askew School of Public Administration and Policy at Florida State University. His research interests include institutions and organizations, local governance, economic development policy, and local fiscal policy. E-mail: pjs7511@kmu.ac.kr.

Manuscript received June 10, 2013; out for review June 25, 2013; review completed August 2; accepted August 6, 2013.

The Korean Journal of Policy Studies, Vol. 28, No. 2 (2013), pp. 25-48.

(C) 2013 by the GSPA, Seoul National University 


\section{INTRODUCTION}

Citizen participation in administrative processes has received much attention from public administration scholars because citizen activities in social and political networks can reduce citizens' negative perceptions of government policies (Berman, 1997; Park \& Hwang, 2009).Despite such benefits, the literature has not provided detailed explanations of why governments use such participation mechanisms. Studies have noted external forces that encourage governments to select citizen participation programs (Ebdon \& Franklin, 2006; Yang \& Callahan, 2007). These include pressure from external stakeholders (Yang \& Callahan, 2007), government structure (Nalbandian, 1991; Yang \& Callahan, 2005), community environments and cultures (Ebdon, 2000; Wang, 2001), and legal constraints (Ebdon \& Franklin, 2006). Despite such empirical evidence, prior studies have not investigated the impacts of politics on the adoption of citizen participation programs. Public management studies have emphasized that public bureaucracy is constrained by political influences because various external stakeholders attempt to control bureaucracy to maximize their political interests (Pandey \& Wright, 2006; Waterman, Rouse, \& Wright, 2004).

This article calls attention to external political institutions because different types of political institutions lead local bureaucrats to increase or decrease the use of citizen participation programs. From the institutional perspective, citizen participation programs are institutions created by operational rules. Institutional theories explain that multiple levels of institutions exist within a community, and higher-level institutions affect lower-level institutions (McCabe \& Feiock, 2005; Ostrom, 2005; Williamson, 2000). For example, political institutions at the constitutional level can affect the use of citizen participation programs at the operational level. Different types of political institutions create different external environments. The variety and use of citizen participation mechanisms are constrained by these external environments.

Few studies have examined the effects of political institutions on citizen participation programs, but they have examined the form of government (Kweit \& Kweit, 1981; Nalbandian, 1991; Yang \& Callahan, 2007). This study explores a missing link by asking the following question: What political institutions encourage local governments to adopt citizen participation programs, despite the increased costs? To answer this question, it builds upon the institutional perspective on citizen participation and empirically examines whether political institutions affect the variety and use of citizen participation programs at the local level.

The article proceeds as follows. First, it reviews prior studies that have examined the antecedents of citizen participation. Next, it develops a theoretical framework and hypotheses by integrating multilevel institutional theories, rational choice theory, and 
transaction cost theory. Focusing on the variables of political institutions and citizen participation programs, it empirically tests a few models that explain the associations among these variables. Lastly, it discusses the findings, implications, and limitations of the study.

\section{LITERATURE REVIEW: THE ANTECEDENTS OF CITIZEN PARTICIPATION}

Citizen participation has been defined as "citizens' involvement in the administrative decision making and management process" (Yang \& Pandey, 2011, p.880). Citizen participation improves democratic values by directly reflecting citizens' preferences, but it entails administrative costs such as delayed decisions and the loss of decision-making control (Irvin \& Stransbury, 2004; Moynihan, 2003). Prior normative and empirical studies have examined what factors motivate administrators to use citizen participation mechanisms.

First, scholars have noted internal contexts, such as the purpose and attributes of decisions, that lead administrators to use citizen involvement programs. The literature indicates that governments use citizen participation mechanisms for the purpose of manipulation, discovery, persuasion, and legitimization (Arnstein, 1969; Walters, Aydelotte, \& Miller, 2000). In a classical work, Arnstein (1969) suggests a ladder of citizen participation and argues that bureaucrats take advantage of citizen participation mechanisms to manipulate citizens' opinions at the level of nonparticipation, while the mechanisms improve legitimacy by ensuring citizens' delegated powers at the higher levels of citizen participation. Attributes of administrative decisions also cause government to use citizen participation mechanisms. Thomas (1990) shows in a decisionmaking flow chart that bureaucrats engage in public involvement efforts when they have a lack of information, unstructured problems, and conflicting issues. Trust is also an important internal factor that motivates administrators to establish citizen participation programs. Empirical evidence indicates that administrators are more committed to citizen participation when they trust citizens (Yang, 2005, 2006). These studies describe the internal contexts that arise when explaining why governments adopt citizen participation mechanisms.

Other studies have focused on external contexts that drive administrators to use citizen participation mechanisms despite increased internal costs (Ebdon, 2000; Ebdon \& Flankin, 2006; Kweit \& Kweit, 1981; Miller \& Evers, 2002; Nalbandian, 1991; Wang, 2001; Yang \& Kallahan, 2007). Yang and Callahan (2007) find that both push and pull factors affect citizen involvement efforts and that external stakeholders push 
administrators to undertake such efforts. Studies have also found that the councilmanager form of government and large population size are external forces that lead to the adoption of citizen participation programs at the local level. Professional managers in the council-manager form of government are eager to seek citizens' input to maintain their reputations (Ebdon, 2000; Kweit \& Kweit, 1981; Wang, 2001; Yang \& Callahan, 2007).

Large local governments have increased citizens' access to decision-making processes due to diverse groups' demands (Protasel, 1988; Nalbandian, 1991). The extent to which a participatory culture is embedded in administrators' and citizens' perceptions also affects the degree of citizen participation. Governments are more likely to implement citizen participation programs when they experience citizen participatory cultures within an administrative process (Ebdon, 2002; Kweit \&Kweit, 1981; Miller \& Evers, 2002). Lastly, legal constraints are an external environmental factor that compels local governments to adopt citizen participation programs. Many states legally require local governments to include citizens' input in budgetary processes (Ebdon \& Flankin, 2006).

\section{THEORETICAL BACKGROUND: AN INSTITUTIONAL PERSPECTIVE ON CITIZEN PARTICIPATION}

Although prior empirical studies have discovered the external determinants of citizen participation, few studies have investigated the impacts of political institutions on the use of citizen participation. Given that politics and administration are closely interconnected (Rainey, 2003), there is a need to explore the missing links between politics and citizen participation in administrative decision-making processes. To address this issue, this article builds upon the institutional perspective on citizen participation, because citizen participation programs as institutional mechanisms are influenced by political institutions which create different external environments. Stewart (2007) touches on a variety of institutional mechanisms of citizen participation and introduces many institutional mechanisms classified by the level of decision making delegated to citizens. Stewart's study provides a well-designed model to introduce multiple dynamic institutional citizen participation mechanisms, but does not explain how other institutions affect the adoption of various citizen participation programs. Therefore, we still do not know about the other institutions that motivate bureaucrats to design citizen participation programs.

Multilevel institutional theories account for hierarchical links between high-level (constitutional) institutions and low-level (operational) institutions. Ostrom (2005) 
argues that institutions are a set of rules prescribed by participants to achieve predictability within defined situational arenas. These rules have multilevel structures from constitutional choice rules to operational rules. Constitutional-level rules affect operational rules by determining actors' incentive structures in crafting the operational rules (Buchanan \& Tullock, 1962). Similarly, Williamson (2000) classifies institutions into institutional environments (external environmental systems) and institutional arrangements (governance structures designed properly at the organizational level). Institutional environments affect institutional arrangements by motivating actors to design operational institutions. Multilevel institutional theory suggests that the institutional mechanisms of citizen participation at the operational level are influenced by political institutions at the constitutional level, because different political institutions create different institutional environments associated with the adoption of citizen participation.

Figure 1 displays the conceptual logic that explains the hierarchical institutions in relation to political institutions and citizen participation. While different studies have used different terminology, for the purposes of this study local political institutions are considered constitutional (high-level) institutions because they are created by a local constitution (such as a municipal charter), which establishes an institutional

Figure 1. The Institutional Mechanism of Citizen Participation

\section{Institutional Environment}

Constitutional (High)-level Institution: Political Institutions

(e.g. Council Manager Form of Government, At Large Election, Nonpartisan Election)

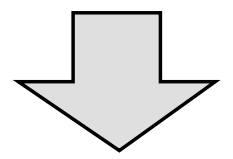

\section{Institutional Arrangement}

Operational (Low)-level Institution: Citizen Participation Programs

(e.g. Citizen Participation Mechanisms: Citizen Board/Commission

Citizen Participation in Management and Functional Areas:

Finance, Economic Development, Transportation) 
environment, and citizen participation programs are considered operational (low-level) institutions because they are created by administrative law, which establishes an institutional arrangement.

Based on this logic, how do political institutions in a municipal charter affect the adoption of citizen participation programs at the operational level? Rational choice theory and transaction cost theory in political science can explain the adoption of citizen participation associated with political contexts. Rational choice theory assumes that elected officials are rational actors who seek to maximize self-interest in relation to reelection. Transaction cost theory accounts for the effects of constitutional institutions on the institutional adoption of citizen involvement efforts. Williamson (1981) regards transaction cost as an important mechanism for institutional change. Rational actors with bounded rationality confront the uncertainty generated by high levels of transaction costs. In a political market, elected officials have high-powered incentive for reelection and confront high levels of transaction costs due to uncertainty about their reelection (Frant, 1996). Therefore, the rational choice of politicians is to seek short-term policies that improve their chances of reelection and attempt to control the local bureaucracy for their own political benefit. In these external environments, local bureaucrats have difficulty designing citizen participation programs because they are more constrained by elected officials' pressures than by citizens' substantive needs.

Early progressive reforms created various political institutions designed to reduce transaction costs by structurally isolating the civil service from politicians seeking shortterm political benefits. When a local bureaucracy is less influenced by politics, public managers seek long-term policies. Citizen participation programs can be good policy tools that help local managers to listen to citizen needs when making long-term policies. Long-term policies produce important policy outcomes due to their broad and durable impacts. Therefore, governments attempt to improve the quality of such significant decision making by reflecting citizens' ideas and opinions (Arnstein, 1969). Public managers also regard citizen participation as a useful tool that legitimizes important administrative or policy decision making because it can reduce citizens' objections or resistance (Moynihan, 2003). Local public managers use citizen participation programs to ensure the quality and legitimacy of long-term decision-making.

\section{HYPOTHESES: \\ POLITICAL INSTITUTIONS AND CITIZEN PARTICIPATION}

Local political structures are particularly salient in explaining the transaction costs associated with political uncertainty because cities in the United States have varied 
political institutions. Frederickson and Johnson (2001) find that US cities are either political or administrative and have adapted over time. They classify cities into five types on a continuum: purely political, adapted political, fully adapted, adapted administrative, and purely administrative. Political cities are characterized by political institutions such as directly elected mayors, councilors elected by district, and partisan elections, and they experience more competition among political coalitions (Frederickson, Johnson, $\&$ Wood, 2003). Administrative cities are characterized by the council-manager form of government, at-large elections, and nonpartisan elections that are designed to structurally shield local bureaucracies from political influences (Keating, 1991).

Administrative cities can increase the long-term effects of policies because the local bureaucracy is less constrained by politicians who seek short-term policy success due to their desire for reelection. For example, in the council-manager form of government, a professional manager appointed by the city council serves instead of an elected mayor. Nonpartisan elections exclude political influences by prohibiting local council members from joining a party. At-large elections reduce political influences such as local interest group lobbying within a narrow jurisdiction by electing local council members across several jurisdictions.

The council-manager form of government creates less uncertainty than the mayorcouncil form of government. The appointment of a professional manager helps protect the local bureaucracy from political influences. In contrast, in the mayor-council form of government, mayors are directly elected by voters and confront political uncertainty, with a powerful incentive to be reelected in the next election. Elected mayors consider constituents' preferences because they are rational actors who seek to maximize their own political benefits. Elected mayors' citizen participation efforts are determined only by their short-term electoral incentives, and they withhold administrative information from citizens when the information opposes their political benefit (Greenstone \& Peterson, 1971). Even though they adopt citizen participation programs, the purpose is likely to be manipulation or "window dressing" to gain citizens' political support, which may lead to citizens' non participation or inauthentic participation (Arnstein, 1969; King, Felety, \& Susel, 1998).

On the other hand, public managers in the council-manager form of government are shielded from political uncertainty and thus adopt various citizen participation programs in order to seek long-term community prosperity without political considerations. Empirical studies have also shown that the council-manager form of government is more likely to pursue citizens' input because professional managers encourage citizen participation in administrative processes (Kweit \& Kweit, 1981; Nalbandian, 1991; Yang \& Kallahan, 2005, 2007; Ebdon, 2002). Professional managers have a more substantive incentive to protect their professional reputations and enhance their careers 
by improving long-term municipal performance. Cities with the council-manager form of government adopt more long-term community economic development policy instruments such as incentive zoning, business attraction plans, and financial incentives than do cities with elected mayors (Feiock, Jeong, \& Kim, 2003; Feiock, Tavares, \& Lubell, 2008). Citizen involvement programs are established to acquire feedback, which improves outcomes because professional managers are familiar with professional tools that capture customer needs (Yang \& Callahan, 2005, 2007).

Hypothesis 1: Local governments with the council-manager form of government are more likely to adopt citizen participation programs.

Nonpartisan elections reduce elected officials' partisan political incentives. Council members or other officials elected in nonpartisan elections are more independent from partisan influences such as patronage. Nonpartisan elections also mitigate transaction costs in the electoral process by diminishing the possibility that voters can identify the party of a political candidate. On the contrary, partisan politicians are strongly controlled by party organizations which are influenced by the demands of constituents or interest groups who support their parties (Mayhew, 1986). Moreover, they need to be reappointed as party candidates in the next election. As a result, partisan elections provide elected officials with incentives to adopt policies that benefit partisan constituents, because partisan politicians' rational choice is to maximize the possibility of reelection by following the party's policies.

Historically, the spoils system appointed public employees who implemented partisan policies (Miller, 1985). These party-oriented policies are short term or inefficient and lose legitimacy due to their politically skewed effects. A citizen participation program is a long-term policy instrument to strengthen legitimacy, despite administrative costs. Accordingly, a municipal government with partisan elections is less likely to engage in citizen involvement efforts because elected officials affiliated with a party do not have incentives to adopt a long-term policy instrument. Furthermore, although partisan elected officials adopt citizen participation programs, the mechanisms may be a citizen mobilization program to promote political participation or may be an inauthentic citizen engagement activity because citizens have a negative perception of the manipulation involved in mobilization programs (Yang \& Callahan, 2007). On the other hand, administrators and elected officials in cities with nonpartisan elections feel less uncertain, since they are well shielded from partisan political influences, which incentivizes them to seek more citizen input into the administrative process because they do not need to consider short-term partisan interests. 
Hypothesis 2: Local governments with nonpartisan elections are more likely to adopt citizen participation programs.

The municipal institutions used to select city council members may determine the level of citizen participation encouraged by local governments. Theoretically, elected officials have powerful incentives due to greater political uncertainty in relation to their constituents' preferences. Local council members' rational choice is to represent dominant stakeholders who can influence their reelection. Council members elected by district consider their constituents' specific interests within districts, while council members selected by at-large elections represent median constituents' interests across districts (Maser, 1998). Empirical evidence indicates that municipalities with at-large elections actively implement civil service reforms, pro-development policies, and fewer impact fees, with reduced external pressures from local stakeholders (Feiock, Jeong, \& Kim, 2003; Feiock, Tavares, \& Lubell, 2008; Ruhil, 2003).

In contrast, district-specific elections lead local governments to adopt pro-environment policies due to the pressure from interest groups who have a dominant power within the district. Local council members elected through at-large elections are less constrained by local interest groups with dominant powers within a narrow electoral district and create rules or policies to secure long-term community performance. Accordingly, local council members will encourage the local bureaucracy to ensure more citizens' inputs in policy processes because they believe that citizen participation is beneficial to long-term prosperity for community prosperity and for average citizens. This study assumes that municipal governments with at-large elections will use more citizen participation programs because council members selected by at-large elections are not constrained by narrow district interests and will push the local bureaucracy to seek broad voter input in the long term.

Hypothesis 3: Local governments with at-large election are more likely to adopt citizen participation programs.

This study also controlled the effects of other factors on the adoption of citizen participation programs. First, the characteristics of local management affect the adoption of citizen participation. For example, local governments with lower budgets may not adopt many citizen participation programs because citizen involvement efforts increase administrative costs. On the other hand, when local governments are actively engaged in performance management and measurement, they establish many citizen participation tools to acquire citizen ideas as well as to measure the quality of public services from citizens' perspectives. To control these effects, this study examined the associations 
between per-capita local spending and performance activities and the use of citizen participation programs.

Community demographic characteristics may also be associated with the adoption of citizen participation mechanisms. This study examined whether population, diversity, education level, or income affects the municipal adoption of citizen participation programs. Among the municipal demographic variables, prior studies identified that population size and heterogeneity are antecedents of citizen participation (Andrew, 2009; Ebdon, 2000; Nalbandian, 1991; Protasel, 1988; Yang \& Callahan, 2005, 2007; Wang, 2001). These studies found that large cities exhibit a more heterogeneous population, leading to increased conflicts because of residents' diverse needs, and thus the cities seek more citizen participation to mitigate the conflicts. The effects of income and educational level on citizen participation were also investigated, because educated residents in wealthy cities are highly interested in local policy and administration.

In addition to city demographics, participatory cultures may affect the adoption of citizen participation. Prior studies found that cities in southern areas with traditional cultures use less citizen involvement programs in their budgetary process (Ebdon, 2000). Metropolitan areas may also be associated with citizen participation, because citizens in urbanized regions have easy access to citizen participation programs.

\section{METHODOLOGY}

\section{Data Collection}

This study collected data from several sources. Data for the dependent variables were taken from the ICMA State of Profession Survey (2006) and the ICMA Municipal Form of Government Survey (2006). The ICMA State of Profession Survey questionnaires were mailed in the spring and summer of 2006 to the chief administrative officers of municipalities with populations more than 2,500 in the United States. Of the 8,003 municipalities and counties that received surveys, 2,870 responded to the survey (response rate: 35.9\%). For the ICMA Municipal Form of Government 2006 Survey, questionnaires were mailed to 8,278 municipalities, also in 2006. A total of 3,864 municipalities responded to the survey (response rate: $46.7 \%$ ).

Data for the explanatory variables came from the ICMA Municipal Form of Government 2006 Survey, the IMCA State of Profession 2006 Survey, the US Census Population (2000), and the US Census Local Government Finance (2002). This study merged these data sets through the SPSS function and removed cities that had missing values in multiple datasets. It ran a series of T-tests comparing the average values of 
the primary variables between the original datasets and the merged dataset to check whether the merged dataset accurately represented the original datasets. The results indicated that the primary variables did not statistically differ between the merged dataset and original datasets $(\mathrm{p}<0.05) .{ }^{1}$

\section{Measurement}

In general, citizen participation is encouraged by establishing operating programs and rules. This study employed two institutional citizen participation variables-citizen participation mechanisms and citizen participation in services and management-as dependent variables (Wang, 2001). The ICMA State of Profession 2006 survey provides data on various citizen participation mechanisms used by local governments. This study identified six citizen participation mechanisms (council meeting, town meeting, neighborhood meeting, citizen board or commission, ad hoc task force, and citizen survey).

The ICMA Form of Government 2006 survey identified citizen involvement mechanisms din 23 service areas and management functions. Out of these, this study selected 10 - transportation, zoning, finance, civil service, police and safety, libraries, housing, economic development, code enforcement, and parks and recreation-suggested by the previous literature (Wang, 2001). The dependent variables were measured by the number of citizen participation mechanisms and citizen participation in services and management functions. To test the validity of the dependent variables, this study ran a factor analysis, conducting the Varimax rotation, which is commonly recommended. Most variables were distinctly explained by two latent factors, except the town meeting (factor loading: 0.291) and the use of citizen participation in the civil service (0.288). This study dropped those two variables. Table 1 reports the factor loadings explained by each dimension of the citizen participation program.

For the independent variables, first, the institutional variables such as form of government, at-large council elections, and nonpartisan elections were employed from the ICMA Form of Government 2006 Survey. If a local government had a councilmanager form of government, it was coded as 1 , otherwise as 0 . To measure nonpartisan elections, this study examined whether the council candidates had a political party affiliation in the election. Nonpartisan election was coded as 1 if the local election

1. The mean numbers of citizen involvement mechanisms were 3.68 and 3.64 in the merged dataset and the ICMA State of Profession 2006, respectively. The mean numbers of citizen involvement in services and management functions were 3.40 and 3.29 in the merged data set and the ICMA Municipal Form of Government 2006, respectively. 
Table 1. Factor Analysis

\begin{tabular}{l|c|c}
\hline & $\begin{array}{c}\text { Factor 1: Citizen participation } \\
\text { mechanisms }\end{array}$ & $\begin{array}{c}\text { Factor 2: Citizen participation } \\
\text { in services and management }\end{array}$ \\
\hline Council meeting & -0.077 & $\underline{0.570}$ \\
\hline Town meeting & -0.050 & 0.291 \\
\hline Neighborhood meeting & 0.135 & $\underline{0.554}$ \\
\hline Citizen board/commission & 0.037 & $\underline{0.694}$ \\
\hline Ad hoc task force & 0.108 & $\underline{0.624}$ \\
\hline Citizen survey & 0.034 & $\underline{0.470}$ \\
\hline Transportation & $\underline{0.481}$ & 0.288 \\
\hline Zoning & $\underline{0.568}$ & -0.111 \\
\hline Finance & $\underline{0.463}$ & 0.120 \\
\hline Civil service & 0.288 & -0.071 \\
\hline Police/safety & $\underline{0.502}$ & 0.007 \\
\hline Economic development & $\underline{0.552}$ & 0.107 \\
\hline Code enforcement & $\underline{0.389}$ & 0.028 \\
\hline Parks/recreation & $\underline{0.553}$ & 0.041 \\
\hline Libraries & $\underline{0.493}$ & -0.079 \\
\hline Housing & $\underline{0.537}$ & 0.084 \\
\hline Rotaton & &
\end{tabular}

Rotation-Varimax.

ballot did not show a political party affiliation for the council candidate, otherwise as 0 . For the council elections, this article also coded local governments with council members selected by at-large electionsasland others as 0 .

This study also controlled the effects of management characteristics such as local spending and performance activities on citizen participation. The amount of local spending was measured from the US Census Local Government Finance 2002 by per capita total local expenditure. If local governments were engaged in performance management and measurement activities, this was coded as 1 , and if not, as 0 . The variable was measured from the ICMA State of Profession Survey 2006. Demographic and geographical characteristics were also employed as control variables. This article selected population, diversity, median income, and educational level from the census population data. Population and diversity were measured by per thousand population and the Herfindahl-Hirschman Index ${ }^{2}$ respectively. Income was represented by per

2. Herfindahl-Hirschman Index means how diverse a local jurisdiction is in terms of ethnicity. 
capita income, and educational level was measured by the percentage of residents with more than a bachelor's degrees. Geographic variables were measured by whether cities were located in the southern region or in a metropolitan (central) area, as identified in the ICMA State of Profession Survey. If a city was located in the south, it was coded as 1 , and if not, as 0 . A city in a metropolitan area was coded as 1 , and other cities were coded as 0 . The appendix summarizes these data and their sources.

\section{Analysis}

We ran descriptive analyses to report the number of the citizen participation institutions adopted by local government and tested whether there were differences in the percentage of adoptions across political institutions by a series of chi-square difference tests. We also tested whether political institutions at municipal charter increased the adoption of citizen participation programs using Poisson regression analyses, ${ }^{3}$ because the dependent variables were count variables. ${ }^{4}$ Two models were analyzed to examine the effects of political institutions on two institutional mechanisms of citizen participation.

\section{RESULTS}

Table 2 summarizes the mean, standard deviation, and minimum and maximum values for each variable. The results indicate that, on average, municipal governments in the United States adopt 3.40 citizen participation mechanisms and use citizen participation in 3.24 service and management functions. In the political institutions variables, the mean values of nonpartisan election were the highest (Mean $=0.815$, Standard Deviation $=0.388$, which reveals that most city governments are shielded from partisan

If the value is 1 , the local jurisdiction is the most diverse.

3. The Poisson regression model requires the assumption of equidispersion - the mean value of the dependent variable must be equal to its variance (Hoffman, 2004). The assumption tests showed underdispersion because the mean values are greater than the variances (means: $3.408,3.243$; variances: $1.538,1.990$ ). This study corrected the underdispersion by using robust standard errors in Stata 12; negative binominal regression was used to correct overdispersion.

4. When the dependent variable was a count variable (number), Poisson or negative binominal regression was used. This study also tested the assumptions of OLS regression such as residual normality, homoskedasticity, and multicollinearity in order to check whether the OLS regression was appropriate. The tests found heteroskedasticities in the models, and the Poisson regression analyses were executed instead of the OLS regression. 
Table 2. Descriptive Statistics

\begin{tabular}{l|r|r|r|r|r}
\hline \multicolumn{1}{c|}{ Variable } & N & \multicolumn{1}{c|}{ Mean } & \multicolumn{1}{c|}{ SE } & \multicolumn{1}{c}{ Min } & \multicolumn{1}{c}{ Max } \\
\hline Citizen participation mechanisms & 1,665 & 3.408 & 1.240 & 0 & 5 \\
\hline Citizen participation in services and management & 1,710 & 3.243 & 1.990 & 0 & 9 \\
\hline Council-manager form & 1,710 & 0.651 & 0.475 & 0 & 1 \\
\hline Nonpartisan election & 1,628 & 0.815 & 0.388 & 0 & 1 \\
\hline At-large election & 1,637 & 0.653 & 0.476 & 0 & 1 \\
\hline Per capita local expenditure & 1,478 & 1,393 & 1,021 & 0.010 & 9,800 \\
\hline Performance activity & 1,451 & 0.470 & 0.499 & 0 & 1 \\
\hline Population (per thousand) & 1,493 & 2,516 & 4,739 & 1,415 & 791,353 \\
\hline Diversity (Herfindahl-Hirschman Index) & 1,485 & 0.268 & 0.170 & 0 & 0.728 \\
\hline Per capita income & 1,496 & 22,414 & 11,282 & 6,967 & 112,408 \\
\hline Educational level & 1,496 & 25.23 & 15.46 & 1 & 84 \\
\hline Southern region & 1,710 & 0.282 & 0.450 & 0 & 1 \\
\hline Metropolitan (central) & 1,710 & 0.077 & 0.267 & 0 & 1 \\
\hline
\end{tabular}

local political pressure as a result of municipal reforms that have been implemented since the early progressive government reform. The council-manager form of government and at-large elections had the mean values of 0.651 and 0.653 , respectively, which indicates that $65.1 \%$ and $65.3 \%$ of cities, respectively, have the council-manager form of government and at-large election.

Table 3 presents an additional comparison of the adoptions of citizen participation programs across three political institutions. Overall, municipal governments adopted the most council meetings, and $91.3 \%$ of cities used council meetings for citizen participation. Neighborhood meetings were the least used by municipal governments $(40.5 \%)$. In the use of citizen participation programs in services and management, municipalities used citizen participation programs the most $(79.8 \%)$ in zoning and the least $(12.4 \%)$ in police and safety. The adoption rates for all citizen participation mechanisms were higher in cities with the council-manager form of government and nonpartisan elections than in other cities. The rate of adoption of citizen participation in services and management did not vary across different political institutions.

Following the chi-square difference test, we performed the sequential Poisson regression analyses to test the hypotheses (Table 4). Hypothesis 1 was partially supported, and the council-manager form of government increased the adoption of citizen participation mechanisms (incidence rate ratio or IRR: 1.136, $\mathrm{p}<0.01$ ), ${ }^{5}$ even though it has a partially significant impact on citizen participation in services and management 
Table 3. Adoption Rate of Citizen Participation Institutions across Political Institutions

\begin{tabular}{|c|c|c|c|c|c|c|c|}
\hline & \multirow{2}{*}{$\begin{array}{l}\text { Adoption } \\
\text { rate }\end{array}$} & \multicolumn{2}{|c|}{$\begin{array}{c}\text { Council } \\
\text { manager? }\end{array}$} & \multicolumn{2}{|c|}{$\begin{array}{l}\text { Nonpartisan } \\
\text { election? }\end{array}$} & \multicolumn{2}{|c|}{$\begin{array}{l}\text { At-large } \\
\text { election? }\end{array}$} \\
\hline & & Yes & No & Yes & No & Yes & No \\
\hline \multicolumn{8}{|c|}{ Citizen participation mechanisms (\%) } \\
\hline Council meeting & 91.3 & $94.2^{* *}$ & $86.6^{\star \star}$ & $96.2^{\star \star}$ & $86.7^{\star \star}$ & 90.8 & 93.0 \\
\hline Neighborhood meeting & 40.5 & $46.9^{\star \star}$ & $28.9^{\star *}$ & $43.5^{\star \star}$ & $28.9^{* \star}$ & $33.8^{* *}$ & $44.7^{* *}$ \\
\hline Citizen board/commission & 89.0 & $91.9^{* *}$ & $84.1^{* *}$ & $91.1^{* *}$ & $81.4^{* *}$ & 88.8 & 90.1 \\
\hline Ad hoc task force & 59.4 & $64.4^{\star *}$ & $51.0^{* *}$ & $62.8^{* *}$ & $47.8^{* *}$ & 60.3 & 58.5 \\
\hline Citizen survey & 57.6 & $61.0^{* *}$ & $52.0^{* *}$ & $60.0^{* *}$ & $49.0^{\star \star}$ & 58.6 & 55.4 \\
\hline \multicolumn{8}{|c|}{ Citizen participation in services and management (\%) } \\
\hline Transportation & 21.2 & $25.3^{\star \star}$ & $14.3^{\star *}$ & $22.5^{\star}$ & $16.9^{*}$ & 22.3 & 20.8 \\
\hline Zoning & 79.8 & 79.8 & 79.8 & $79.2^{*}$ & $84.4^{*}$ & $78.5^{*}$ & $83.3^{*}$ \\
\hline Finance & 18.5 & 18.3 & 18.9 & 18.6 & 17.3 & 19.5 & 17.3 \\
\hline Libraries & 38.4 & 38.0 & 39.1 & $40.7^{* \star}$ & $31.6^{* *}$ & $35.1^{* \star}$ & $46.1^{* \star}$ \\
\hline Housing & 26.9 & 27.5 & 26.1 & 27.9 & 22.9 & 24.5 & 30.8 \\
\hline Police and safety & 12.4 & 12.2 & 12.9 & 12.3 & 12.0 & 11.1 & 15.3 \\
\hline Economic development & 38.4 & 39.4 & 36.7 & 39.2 & 35.2 & $36.4^{*}$ & $41.0^{*}$ \\
\hline Code enforcement & 24.1 & $25.7^{\star}$ & $21.4^{*}$ & 23.3 & 26.2 & 23.5 & 25.5 \\
\hline Parks and recreation & 64.2 & $38.6^{*}$ & $34.1^{*}$ & $65.9^{*}$ & $59.6^{*}$ & 65.3 & 63.9 \\
\hline
\end{tabular}

Chi-square difference: ${ }^{*} p<0.05,{ }^{* *} p<0.01$

(IRR: 1.068, $\mathrm{p}<0.1$, threshold: $\mathrm{p}<0.05$ ). This result indicates that local governments with the council-manager form of government adopt $13.6 \%$ more citizen participation mechanisms than local governments with other governmental structures, holding other explanatory variables constant. Hypothesis 2 was partially supported. Nonpartisan elections increased citizen participation mechanisms (IRR: 1.193, p < 0.01), while they did not affect the use of citizen participation in services and management. The result suggests that municipal governments with nonpartisan elections adopt $19.3 \%$ more citizen participation mechanisms than other governments when other explanatory variables are held constant. Hypothesis 3 was fully rejected; at-large elections were

5. Poisson regression uses a log-link function similar to logit regression, and thus coefficients need to be exponentiated to get a meaningful number to interpret. The incidence rate ratio (IRR) deals with the incidence rates of a dependent variable affected by independent variables. 
Table 4. Poisson Regression Results

\begin{tabular}{|c|c|c|c|c|}
\hline & \multicolumn{2}{|c|}{$\begin{array}{l}\text { Citizen participation } \\
\text { mechanisms }\end{array}$} & \multicolumn{2}{|c|}{$\begin{array}{l}\text { Citizen participation in } \\
\text { services and management }\end{array}$} \\
\hline & Coefficient (SE) & IRR & Coefficient (SE) & IRR \\
\hline Council-manager form & $0.128^{* *}(0.249)$ & 1.136 & $0.066^{\#}(0.038)$ & 1.068 \\
\hline Nonpartisan election & $0.160^{* *}(0.338)$ & 1.174 & $-0.002(0.059)$ & 1.000 \\
\hline At-large election & $-0.034^{\#} \quad(0.019)$ & 0.966 & $-0.058 \quad(0.036)$ & 0.943 \\
\hline Per capita local expenditure & $0.021^{\star \star}(0.008)$ & 1.021 & $0.068^{\star *}(0.015)$ & 1.070 \\
\hline Performance activity & $0.110^{* *}(0.019)$ & 1.113 & $0.066^{\# \quad(0.035)}$ & 1.068 \\
\hline Population (per thousand) & $0.006^{\star \star}(0.001)$ & 1.006 & $0.008^{\star \star}(0.002)$ & 1.008 \\
\hline Diversity (Herfindahl-Hirschman Index) & $0.248^{* *}(0.69)$ & 1.128 & $-0.076 \quad(0.127)$ & 0.926 \\
\hline Per capita income & $0.001^{*}(0.001)$ & 1.001 & $-0.001^{* *}(0.000)$ & 0.999 \\
\hline Educational level & $0.005^{\star *}(0.001)$ & 1.005 & $0.005^{\star}(0.002)$ & 1.005 \\
\hline Southern region & $-0.087^{* *}(0.021)$ & 0.916 & $-0.004 \quad(0.040)$ & 0.995 \\
\hline Metropolitan (central) & $0.093^{* *}(0.027)$ & 1.098 & $0.163^{\star *}(0.060)$ & 1.176 \\
\hline $\mathrm{N}$ & \multicolumn{2}{|l|}{1,156} & \multicolumn{2}{|l|}{1,175} \\
\hline Waldo chi-square & \multicolumn{2}{|l|}{$327.77^{\star *}$} & \multicolumn{2}{|l|}{$84.10^{\star \star}$} \\
\hline Pseudo R-square & \multicolumn{2}{|l|}{0.0266} & \multicolumn{2}{|l|}{0.0193} \\
\hline
\end{tabular}

${ }^{\#} p<0.1,{ }^{*} p<0.05,{ }^{* *} p<0.01$

IRR= incidence rate ratio

not associated with either citizen participation mechanisms or citizen participation in services and management.

In the control variables, per capita total local expenditure and performance management and measurement activities are associated with both citizen participation mechanisms and citizen participation in services and management. Population size and city education level were statistically associated with both dependent variables. Per capita income had a positive impact on citizen participation mechanisms, while it negatively affected citizen participation in services and management. Diversity was associated only with citizen participation mechanisms. Central metropolitan areas increased both citizen participation mechanisms and citizen participation in functional areas, while the southern region showed a negative association only with the citizen participation mechanisms. 


\section{IMPLICATIONS AND CONCLUSION}

There have been long debates on the relationship between politics and bureaucracy (Fry, 1998; Shafritz \& Hyde, 2012). The results of this study show that politics influences bureaucratic programs such as citizen participation mechanisms through multilevel institutional dynamics. The findings also demonstrate that political institutions external to local bureaucracies create external environments where local bureaucrats establish a variety of citizen participation institutions at the operational level in response to external influences.

Overall, the findings reveal that political contexts influence only the adoption of citizen participation mechanisms, rather than the substantive use of citizen participation in functional management and policy areas. The results are similar to the findings of a prior study: Yang and Callahan (2007) have found that professional city managers adopt many citizen participation mechanisms, but do not use them in strategic decisionmaking processes for fear of losing their administrative control and powers. Likewise, public managers do not want to lose their administrative control in management and policy areas. Although local bureaucrats establish more citizen participation mechanisms in response to reduced political influence, they may hesitate to substantively use citizen participation in particular service areas and management functions in order not to lose control (Irvin \& Stansbury, 2004).

The findings of this study indicate that the council-manager form of government increases the adoption of citizen involvement mechanisms. These results are consistent with those of prior studies (Ebdon, 2000; Yang \& Callahan, 2005, 2007; Wang, 2001). Specifically, professional managers adopt more citizen participation programs than elected officials because they possess the professional experience and knowledge that identifies citizen's needs (Yang \& Callahan, 2005, 2007). From a political market framework, they have low incentives isolated from political benefits (Frant, 1996) and promote the use of citizen participation to improve governmental performance, whereas elected officials' incentives to promote citizen involvement are contingent on whether citizen participation is beneficial to their reelection.

Nonpartisan elections are another antecedent that pushes local governments to adopt more citizen participation mechanisms. Jackman (1987) finds that a small number of political parties increases voter turnout because less partisan competition encourages citizen political participation. In line with political participation, this finding indicates that local administrators in cities with nonpartisan elections want to create long-term policies that improve citizens' well-being because they are less controlled by local partisan politicians. They believe that citizen participation programs are good instruments to enhance community prosperity by reflecting citizens' needs or demands. 
Lastly, the findings indicate that at-large elections are not directly related to the adoption of either citizen involvement effort. A prior study has argued that, rather, cities where councilors are elected by district seek more citizen input to solve political conflicts within the community (Ebdon, 2000). At-large council elections may drive local administrators to adopt citizen participation programs by shielding them from community-based political influences. Despite such bureaucratic efforts, council members may not be interested in community-based citizen engagement because they represent broad median voter interests across jurisdictions. In cities with at-large elections, council members' weak interests may decrease the adoption of citizen participation programs.

Most control variables are also statistically associated with the two types of citizen participation. Interestingly, per capita total expenditure increases both citizen participation mechanisms and the use of citizen participation in functional areas. Prior studies have argued that citizen participation entails considerable administrative costs (Irvin \& Stansbury, 2004; Moynihan, 2003). The findings imply that local governments adopt more citizen participation mechanism when they can afford the costs of these mechanisms. Governmental efforts to manage and measure local performance lead to greater adoption of administrative participation programs. Local governments can effectively manage and measure local performance by listening to citizens' voices in citizens' boards or public hearings and conducting more citizen surveys.

Large and diverse cities establish many citizen participation channels to identify complex service needs within their communities, and highly educated residents push the local bureaucracy to adopt more citizen participation programs due to their interest in and knowledge of policy processes (Nalbandian, 1991; Protasel, 1988). Wealthy cities can afford to establish many citizen participation mechanisms. Cities in the southern region use fewer citizen participation programs than cities in other regions because their elite-oriented political cultures do not include strong citizen participatory traditions (Ebdon, 2000). The findings also show that cities in metropolitan areas adopt more citizen involvement mechanisms. Just like large cities, cities in metropolitan areas need to provide complex services that satisfy diverse population groups, which may increase their use of citizen participation mechanisms.

The results of this study suggest theoretical and practical implications for citizen involvement efforts. One theoretical implication is that the study discovered new external antecedents of citizen participation from the institutional perspective. Highlevel political institutions such as nonpartisan elections increase the adoption of citizen participation programs at the operational level. In particular, the findings confirm the classical argument that politics are interconnected with public administration. Given that politics strongly affects the public bureaucracy, this study theoretically clarifies how politics affects bureaucratic practices such as citizen participation. The adoption 
mechanisms are explained by elected officials' rational choices and uncertainties in institutional environments created by different political institutions. In other words, a public bureaucracy can use more participatory mechanisms for long-term polices when it is less constrained by politicians who consider only short-term policies associated with their reelection.

From the sociological institutional perspective, local governments adopt bureaucratic institutions such as citizen participation due to isomorphic mechanisms without calculating their benefits. However, our findings show that from the new economic institutional perspective, elected officials' incentives maximizing their political benefits are associated with how many citizen participation tools local government use. These findings can provide further insights on how political contexts influence bureaucratic practices such as red tape, contracting, and policy implementation programs in addition to citizen participation.

A practical implication of the study is that it encourages practitioners to rethink the rationales of early progressive municipal reforms, which were intended to shield local bureaucracies from negative political forces. The results indicate that such reform efforts still are applicable in current management and policy practices. Practitioners should consider designing local executive and electoral institutions that protect local bureaucracies from short-term political influences, because these institutions encourage local governments to adopt more citizen participation programs for developing longterm policies. In particular, our findings provide a useful practical implication from the US experience for developing countries that want to encourage citizen participation. For example, the Korean Congress recently decided to replace partisan elections with nonpartisan elections at the municipal level because the partisan elections had engendered many side effects such as corruption and poor local performance. In addition to decreased side-effects, local structural reforms excluding political influences may help local governments use more citizen participation programs to enhance the long-term effects of local policies.

This study also has a few limitations. First, it employed only two dimensions of citizen participation as dependent variables. Prior studies identified multidimensional constructs of citizen involvement efforts and their purposes and objectives (Wang, 2001; Yang \& Callahan, 2005). In addition, the number of citizen participation programs used by a local government was measured only by how many participatory tools a local government has rather than the actual implementation of citizen participation or how many citizens participate in these programs. Therefore, our study was not able to establish a clear association between political institutions and citizen participation. Future studies need to test the effects of political institutions on other dimensions of citizen participation and actual implementation of citizen participation. Further study 
is also needed to empirically examine whether citizen participation programs improve government performance and community outcomes. Finally, the focus of this study was on the United States, and political contexts in other countries may differ. The impacts of local politics on citizen participation need to be investigated in a broader range of countries.

In spite of these limitations, this study is an initial step in understanding the institutional contexts surrounding citizen participation by clarifying the external factors that drive local governments to establish citizen participation programs.

\section{REFERENCES}

Andrew, R. 2009. Civic engagement, ethnic heterogeneity, and social capital in urban areas: Evidence from England. Urban Affairs Review, 44(3): 428-440.

Arnstein, S. 1969. A ladder of citizen participation. Journal of the American Institute of Planners, 35(4): 216-224.

Berman, E. 1997. Dealing with cynical citizens. Public Administration Review, 57(2): 105-123.

Buchanan, J., \& Tullock, G.1962. The calculus of consent: Logical foundations of constitutional democracy. Ann Arbor, MI: University of Michigan Press.

Ebdon, C. 2000. The relationship between citizen involvement in the budget process and city structure and culture. Public Productivity \& Management Review, 23(3): 383-393.

Ebdon, C. 2002. Beyond the public hearing: Citizen participation in the local government budget process. Journal of Public Budgeting, Accounting and Financial Management, 14(2): 273-294.

Ebdon, C., \& Franklin, A. 2006. Citizen participation in budgeting theory. Public Administration Review, 66(3): 437-447.

Feiock, R., Jeong, M., \& Kim, J. 2003. Credible commitment and council manager government: Implications for policy instrument choice. Public Administration Review, 63(5): 568-577.

Feiock, R., Tavares, A., \& Lubell, M. 2008. Policy instrument choices for growth management and land use regulation. Policy Studies Journal, 36: 461-480.

Frant, H. 1996. High-powered and low-powered incentives in the public sector. Journal of Public Administration and Theory, 6(3): 365-381.

Fredrickson, G., \& Johnson, G. 2001. The adapted American city: A study of institutional dynamics. Urban Affairs Review, 36(6): 872-884.

Fredrickson, G., Johnson, G., \& Wood, C. 2003. The adapted American city: Institutional 
dynamics and structure change. New York: M.E. Sharpe.

Fry, B. 1998. Mastering public administration: From Max Weber to Dwight Waldo. Washington, DC: CQ Press.

Fung, A. 2006. Varieties of participation in complex governance. Public Administration Review [Special issue on collaborative public management]: 66-75.

Greenstone, D., \& Peterson, P. 1973. Race and authority in urban politics: Community participation and the war on poverty. New York: Russell Sage Foundation.

Hoffman, J. 2004. Generalized linear models: An applied approach. New York: Pearson.

Irvin, R., \& Stansbury, J. 2004. Citizen participation in decision making: Is it worth the effort? Public Administration Review, 64(1): 55-65.

Jackman, R. 1987. Political institutions and voter turnout in the industrial democracies. American Political Science Review, 81(2): 405-424.

Keating, M. 1991. Comparative urban politics. Worcester, MA: Billing \& Son.

King, C., Feltey, K., \& Susel, B. 1998. The question of participation: Toward authentic public participation in public administration. Public Administration Review, 58(4): 317-326.

Kweit, M., \& Kweit, R. 1981. Implementing citizen participation in a bureaucratic society: A contingency approach. New York: Praeger.

Maser, S. 1998. Constitutions as relational contracts. Journal of Public Administration Research and Theory, 8(4): 527-564.

Mayhew, D. 1986. Placing parties in American politics: Organization electoral settings, and government activity in the twentieth century. Princeton, NJ: Princeton University Press.

McCabe, B., \& Feiock, R. 2005. Nested levels of institutions: State rules and city property taxes. Urban Affairs Review, 40(5): 634-654.

Miller, G. 1985. Progressive reform as induced institutional preferences. Public Choice, 47(1): 163-181.

Miller, G., \& Evers, L. 2002. Budgeting structures and citizen participation. Journal of Public Budgeting, Accounting and Financial Management, 14(2): 233-272.

Moynihan, D. 2003. Normative and instrumental perspectives on public participation: Citizens summits in Washington D.C. American Review of Public Administration, 33: $164-188$.

Nalbandian, J. 1991. Professionalism in local government: Transformations in the roles, responsibilities, and values of city managers. San Francisco, CA: Jossey-Bass.

Ostrom, E. 2005. Understanding institutional diversity. Princeton, NJ: Princeton University Press.

Pandey, S., \& Wright, B. 2006. Connecting the dots in public management: Political environment, organizational goal ambiguity and the public manager's role ambi- 
guity. Journal of Public Administration Research and Theory, 16(4): 511-532.

Park, S., \& Hwang, D. 2009. The impact of social capital on satisfaction with national policy. Korean Journal of Policy Studies, 23(2): 201-223.

Poister, T., \& Streib, G. 1999. Performance measurement in municipal government: Assessing the state of the practice. Public Administration Review, 59(4): 325-335.

Protasel, G. 1988. Abandonments of the council-manager plan: A new institutional perspective. Public Administration Review, 48(4): 807-812.

Rainey, H. 2003. Understanding and managing public organizations. San Francisco, CA: Jossey-Bass.

Ruhil, A.2003. Urban armageddon or politics as usual: The case of municipal civil service reform. American Journal of Political Science, 47: 159-170.

Shafritz, J., \& Hyde, A. 2012. Classics of public administration. Australia: Wadsworth/ Cengage Learning.

Stewart, K. 2007. Write the rules and win: Understanding citizen participation game dynamics. Public Administration Review, 67(6): 1067-1076.

Thomas, J. 1990. Public involvement in public management: Adapting and testing a borrowed theory. Public Administration Review, 50(4): 435-445.

Walters, L., Aydelotte, J., \& Miller. J. 2000. Putting more public in policy analysis. Public Administration Review, 60(4): 349-359.

Wang, X. 2001. Assessing public participation in US cities. Public Performance \& Management Review, 24(4): 322-336.

Waterman, R., Rouse,A., \& Wright, R. 2004. Bureaucrats, politics, and the environment. Pittsburgh: University of Pittsburg Press.

Williamson, O. 1981. The economics of organization. American Journal of Sociology, 87: $548-577$.

Williamson, O. 2000. The new institutional economics: Taking stock, looking ahead. Journal of Economic Literature, 38(3): 595-613.

Yang, K. 2005. Public administrators' trust in citizens: A missing link in citizen involvement efforts. Public Administration Review, 65(3): 273-285.

Yang, K. 2006. Trust and citizen involvement decisions: Trust in citizens, trust in institutions, and propensity to trust? Administration \& Society, 38(5): 573-595.

Yang, K., \& Callahan, K. 2005. Assessing citizen involvement efforts by local government. Public Performance \& Management Review, 29(2): 191-216.

Yang, K., \& Callahan, K. 2007. Citizen involvement efforts and bureaucratic responsiveness. Public Administration Review, 67(2): 249-264.

Yang, K., \& Pandey, S. 2011. Further dissecting the black box of citizen participation: When does citizen involvement lead to good outcomes? Public Administration Review, 71(6): 880-892. 


\section{APPENDIX: VARIABLES AND DATA SOURCES}

\section{Dependent Variables}

Citizen Participation Mechanisms (Source: ICMA State of Profession 2006)

When local government offers opportunities for citizen engagement in community problem solving and decision making, please identify the opportunities for citizen engagement.

- Council meeting

- Neighborhood meeting

- Citizen participation on boards or commissions

- Ad hoc task force

- Citizen survey

Citizen Participation in Functional Areas (Source: ICMA Municipal Form of Government 2006) When your municipality has citizen authorities, boards, or commissions, in which areas are they used?

- Transportation

- Zoning

- Finance

- Libraries

- Housing

- Police and safety

- Economic development

- Code enforcement

- Parks and recreation

\section{Explanatory Variables}

Political Institutions (Source: ICMA Municipal Form of Government 2006)

- Form of government: council-manager $=1$; otherwise $=0$

- Nonpartisan election: no party affiliation appears on the ballot in council elections $=1$; otherwise $=0$

- At-large council: councilor elected by all in at-large election $=1$; otherwise $=0$

Management (Sources: US Census Local Government Finance 2002, ICMA State of Profession 2006)

- Local expenditure: per capita total local expenditure 
- Performance activities: performance management and measurement activities: yes $=1 ;$ no $=0$

Demographics (Source: US Census Population 2000)

- Population: population per thousand

- Diversity: Herfindahl-Hirschman Index [1- $\sum$ (percentage of each ethnicity)^2 ]

- Income: per capita income

- Educational level: percentage of residents with more than a bachelor's degree

Geography (Source: ICMA State of Profession 2006)

- South: southern region=1; north central, northeast, and western regions $=0$

- Metropolitan area: central metropolitan area $=1$, independent and suburban areas $=0$ 